\title{
PENGARUH SANITASI LINGKUNGAN TEMPAT TINGGAL DAN KARAKTERISTIK SOSIAL EKONOMI RUMAH TANGGA TERHADAP TERJADINYA DIARE PADA BALITA DI NTT (ANALISIS LANJUT DATA SUSENAS 2012)
}

\author{
Martin Suanta* \\ Pasca Sarjana Program Studi Ilmu Lingkungan, Universias Undana, Kupang \\ "Email : martin@bps.go.id
}

\begin{abstract}
Diarrhea is one of the main reasons of infant mortality in Indonesia. Diarrhea is also a negative impact of interaction between human beings and the environment. The aims of reasearch to know the influence of environment sanitation of house area and social economical characteristics of household toward diarrhea at infant in NTT. Design used secondary data from Susenas 2012 by using household sample for 4 triwulan as many as 10,702 household in all the regencies/city. Unit of analysis consists of both household having infants suffer diarrhea and infants did not suffer from diarhea, so that the amount of household that was researched were as many as the amount of infants in the household namely 5.783. The analysis method was descriptive analysis and inferensial, meanwhile the tool of statistics was by using the logistics regression. The result showed that the variable influences diarrhea at children under five years based on logistics regression was environment sanitation that was non-improved source $(O R=1.484 ; 95 \% C I=1.180$ 1.867), source of water that was non-improved source $(O R=1.516 ; 95 \% C I=1.097$ $2.095)$, type of tile from soil $(O R=1.439 ; 95 \% C I=1.139-1.818)$, age of infant less than 24 month $(O R=1.294 ; 95 \% C I=1.043-1.606)$, education of household is low $(O R=$ $1.412 ; 95 \% C I=1.010-1.973)$, and without breast feeding $(O R=1.898 ; 95 \% C I=1.001$ 3.601). There was a significant relationship between source of water, condition of improved source sanitation, type of tool, age of children under five years, education of the head of household, and breast feeding with the diarrhea at children under five years ( $p=$ 0.000). The risk factor that was proved to influence diarrhea at children under five years was source of water that was non-improved source, condition of environment of house area that was not healthy, type of tile from soil, age of infant less than 2 year, education of the head of household was low, and there was no breast feeding given.
\end{abstract}

Keywords: environment; sanitation; children under five years; diarrhea

\begin{abstract}
Abstrak
Diare adalah salah satu penyebab utama kematian bayi di Indonesia. Diare juga merupakan dampak negatif dari interaksi antara manusia dan lingkungan. Tujuan penelitian untuk mengetahui pengaruh sanitasi lingkungan lingkungan rumah dan karakteristik ekonomi sosial rumah tangga terhadap diare pada bayi di NTT. Data menggunakan data
\end{abstract}


sekunder dari Susenas 2012 dengan menggunakan sampel rumah tangga selama 4 Triwulan sebanyak 10.702 rumah tangga di seluruh kabupaten / kota. Unit analisis terdiri dari rumah tangga yang memiliki bayi menderita diare dan bayi tidak menderita diare, sehingga jumlah rumah tangga yang diteliti adalah sebanyak jumlah bayi di rumah tangga yaitu 5,783. Metode analisis yang digunakan adalah analisis deskriptif dan inferensial, sementara statistik digunakan adalah regresi logistik. Hasil penelitian menunjukkan bahwa variabel yang mempengaruh diare pada anak di bawah lima tahun berdasarkan regresi logistik adalah sanitasi lingkungan yang tidak baik $(\mathrm{OR}=1,484 ; 95 \% \mathrm{CI}=1,180-1,867)$, sumber air yang tidak baik ( $\mathrm{OR}=1,516 ; 95 \% \mathrm{CI}=1,097-2,095)$, jenis genteng dari tanah $(\mathrm{OR}=$ $1,439 ; 95 \% \mathrm{CI}=1,139-1,818)$, usia bayi kurang dari 24 bulan $(\mathrm{OR}=1,294 ; 95 \% \mathrm{CI}=$ 1,043 - 1,606), pendidikan rumah tangga rendah $(\mathrm{OR}=1,412 ; 95 \% \mathrm{CI}=1,010-1,973)$, dan tanpa menyusui $(\mathrm{OR}=1,898 ; 95 \% \mathrm{CI}=1,001-3,601)$. Ada hubungan yang signifikan antara sumber air, kondisi sumber sanitasi, usia anak-anak di bawah lima tahun, pendidikan kepala rumah tangga, dan menyusui dengan diare pada anak di bawah lima tahun ( $\mathrm{p}=$ 0,000 ). Faktor risiko yang terbukti mempengaruhi diare pada anak di bawah lima tahun adalah sumber air yang tidak baik, kondisi lingkungan daerah rumah yang tidak sehat, jenis genteng dari tanah, usia bayi kurang dari 2 tahun, pendidikan kepala rumah tangga yang rendah, dan tidak ada menyusui diberikan.

Kata kunci: lingkungan; sanitasi; bayi dibawah lima tahun; diare

\section{Pendahuluan}

Lingkungan merupakan segala sesuatu yang ada di sekitar kita, baik hidup maupun tidak, seperti udara, air, tanah dengan segala yang ada di atasnya seperti tumbuhan, hewan, mikroorganisme (Chiras, 1991). Menurut Irwan Z.D (2010), penggolongan faktor-faktor lingkungan dapat dibagi menjadi dua kategori yaitu: (1) lingkungan abiotik seperti suhu, udara, cahaya atmosfer, hara mineral, air, tanah, api, (2) lingkungan biotik yaitu makhluk-makhluk hidup diluar lingkungan abiotik. Kemudian Soemarwoto dalam Herwandi Y, dkk (2008) menyebutkan bahwa lingkungan hidup adalah ruang yang ditempati suatu makhluk hidup bersama dengan benda hidup maupun tak hidup. Sifat-sifat lingkungan hidup ditentukan oleh (1) jenis dan jumlah masing-masing unsur lingkungan tersebut, (2) hubungan atau interaksi antara unsur lingkungan hidup tersebut, (3) kelakuan atau kondisi unsur lingkungan hidup, dan (4) faktor non materiil seperti cahaya, suhu, dan kebisingan. Manusia berinteraksi dengan lingkungan hidupnya. Ia mempengaruhi dan dipengaruhi oleh lingkungan hidupnya. Ia membentuk dan terbentuk oleh lingkungan hidupnya. Interaksi manusia dengan lingkungan hidupnya sangatlah komplek karena pada umumnya pada lingkungan hidup tersebut terdapat banyak unsur. Pengaruh terhadap suatu unsur akan merambat pada unsur lain, sehingga pengaruhnya pada manusia sering tidak dapat dengan segera dilihat dan dirasakan.

Salah satu penyakit yang merupakan dampak negatif interaksi manusia dan lingkungannya adalah diare. Diare merupakan penyakit yang menjadi masalah kesehatan dunia, terutama di negara-negara berkembang. Pada tahun 2000 WHO memperkirakan terjadi 4 milyar kasus terjadi dan 2,2 juta diantaranya meninggal dan sebagian besar merupakan anak-anak di bawah 5 tahun (Adisasmito, 2007). Bayi dan balita sangat rentan terhadap penyakit diare, bila tidak segera diatasi dengan tindakan yang tepat dapat mengakibatkan kematian. Data terakhir dari Departemen Kesehatan menunjukkan bahwa diare menjadi penyakit pembunuh kedua bayi di bawah 
lima tahun (balita) di Indonesia setelah radang paru atau pneumonia (Adisasmito, 2002).

Berdasarkan hasil Survei Demografi dan Kesehatan Indonesia (SDKI) tahun 2012, delapan belas persen anak yang berasal dari rumah tangga yang memiliki sumber air minum tidak layak (nonimproved source) menderita diare dibandingkan dengan 14 persen anak yang tinggal dalam rumah tangga yang memiliki sumber air minum layak (improved source). Selain itu, prevalensi diare dari anak yang tinggal dalam rumah tangga yang tidak mempunyai fasilitas toilet dan mereka yang tinggal dalam rumah tangga yang memiliki toilet tanpa tangki septik, lebih rendah dibandingkan dengan anak yang tinggal dalam rumah dengan fasilitas toilet jenis lain.

Laporan Program Pembangunan dari United Nation for Development Programme (UNDP) Perserikatan Bangsa-bangsa (PBB) mengenai status pencapaian Tujuan Pembangunan Manusia atau Milenium Development Goals (MDGs) di Indonesia mengalami kemunduran. Pada tahun 2015, MDGs mencanangkan 69 persen penduduk Indonesia dapat mengakses air minum yang layak dan 72,5 persen memperoleh layanan sanitasi yang memadai. Faktanya, hanya 18 persen penduduk yang memiliki akses ke sumber air minum dan sekitar 45 persen mengakses sarana sanitasi yang memadai (Adisasmito, 2007).

Berdasarkan hasil Riset Kesehatan Dasar (Riskesdas) tahun 2007, Prevalensi diare klinis adalah 9,0\% (rentang: 4,2\% - 18,9\%), tertinggi di Provinsi NAD (18,9\%) dan terendah di DI Yogyakarta (4,2\%). Beberapa provinsi mempunyai prevalensi diare klinis > 9\% (NAD, Sumatera Barat, Riau, Jawa Barat, Jawa Tengah, Banten, Nusa Tenggara Barat, Nusa Tengara Timur, Kalimantan Selatan, Sulawesi Tengah, Sulawesi Tenggara, Gorontalo, Papua Barat dan Papua).

Berdasarkan hasil Survei Sosial dan Ekonomi Nasional (Susenas) 2012, ditemukan sekitar 38 ribu atau 6,53 persen anak balita di Provinsi Nusa Tenggara Timur terserang diare. Angka ini tersebar di seluruh kabupaten/kota yang ada di Provinsi Nusa Tenggara Timur.
Selain itu dari hasil Survei Demografi dan Kesehatan Indonesia (SDKI) Tahun 2012, secara nasional ada 14 persen anak balita mengalami diare dalam dua minggu sebelum survei. Sedangkan di NTT anak balita yang mengalami diare hingga mencapai 17 persen (SDKI2012).

Dari fakta tersebut maka muncul rumusan permasalahan yaitu apa saja yang mempengaruhi terjadinya diare pada balita? Rumusan masalah ini dapat dikemukakan dengan pertanyaan-pertanyaan penelitian sebagai berikut:

a. Apakah faktor sanitasi lingkungan tempat tinggal memberikan kecenderungan terhadap terjadinya diare pada balita di Nusa Tenggara Timur?

b. Apakah karakteristik sosial ekonomi rumah tangga memberikan kecenderungan terhadap terjadinya diare pada balita dalam rumah tangga di Nusa Tenggara Timur?

c. Seberapa besar faktor sanitasi lingkungan tempat tinggal berpengaruh terhadap terjadinya diare pada balita di Nusa Tenggara Timur?

d. Seberapa besar pengaruh karakteristik sosial ekonomi rumahtangga terhadap terjadinya diare pada balita di Nusa Tenggara Timur?

Tujuan dari penelitian ini adalah untuk mengetahui apakah faktor sanitasi lingkungan memberikan kecenderungan terhadap terjadinya diare pada balita, mengetahui apakah karakteristik sosial ekonomi rumahtangga memberikan kecenderungan terhadap terjadinya diare pada balita, mengetahui besarnya pengaruh faktor sanitasi lingkungan tempat tinggal terhadap terjadinya diare pada balita, dan mengetahui besarnya pengaruh karakteristik sosial ekonomi rumahtangga terhadap terjadinya diare pada balita.

\section{Metode Penelitian}

Desain penelitian ini dengan meggunakan data sekunder Susenas 2012. Pengumpulan data Susenas dilakukan melalui wawancara langsung yang dilakukan oleh petugas BPS kabupaten/kota. Jenis data yang dikumpulkan melalui kuesioner Kor (VSEN2012.K) mencakup keterangan antara 
lain: karakteristik anggota rumahtangga, kesehatan, pendidikan, perumahan, sosial ekonomi, dan lain sebagainya. Jenis data yang dikumpulkan melalui kuesioner Modul (VSEN2012.M) mencakup tentang konsumsi makanan dan keterangan tentang pengeluaran rumahtangga untuk bukan makanan. Pada penelitian ini data diperoleh dari BPS Provinsi Nusa Tenggara Timur yang kemudian dilakukan penelusuran data dan dipilih variabel-variabel yang tersedia sesuai dengan tujuan penelitian.

\subsection{Operasionalisasi Variabel}

Variabel terikat atau variabel respon dan variabel-variabel bebas atau variabel penjelas dalam penelitian ini, secara keseluruhan diambil dari beberapa pertanyaan yang ada dalam Susenas 2012. Untuk menentukan variabel-variabel dalam penelitian ini, diperlukan teknik pengolahan data lebih lanjut.

Variabel tak bebas dalam penelitian ini adalah kejadian kasus diare pada balita dalam rumah tangga yang didefinisikan dengan notasi Y. Variabel ini diperoleh dengan cara mengolah data dari hasil Susenas 2012 dengan kuesioner VSEN12.K pada pertanyaan di Blok V.A rincian1e. Kategori yang digunakan dalam variabel ini adalah sebagai berikut:

$\mathrm{Y}=1$; bila ada kejadian diare pada balita dalam rumah tangga

$\mathrm{Y}=0$; bila tidak ada kejadian diare pada balita dalam rumah tangga

Variabel bebas, proksi untuk sanitasi lingkungan lingkungan tempat tinggal responden diwakili oleh variabel-variabel: 1) air minum layak; 2) sanitasi layak; dan 3) keberadaan lantai rumah, sedangkan karakteristik sosial ekonomi rumah tangga akan diambil variabel-variabel: 4) usia balita; 5) pendidikan kepala rumah tangga; 6) pemberian ASI; dan 7) keadaan ekonomi rumah tangga, yang diukur dari distribusi pengeluaran rumah tangga.

\section{a. Sumber Air Minum $\left(\mathrm{X}_{1}\right)$}

Variabel sumber air minum layak ini mengacu dari konsep yang digunakan dalam MDGs oleh BPS, yaitu air mimum yang bersumber dari air leding, sumur bor/pompa, sumur terlindung, mata air terlindung, dan air hujan. Khusus untuk air minum yang bersumber dari sumur bor/pompa, sumur terlindung dan mata air terlindung harus memiliki jarak $\geq 10$ meter dari penampungan akhir tinja terdekat. Air kemasan tidak dikategorikan sebagai air layak karena tidak memenuhi unsur berkelanjutan/sustainability (MDGs, 2007). Variabel ini diperoleh dengan cara mengolah data dari pertanyaan pada kuesioner VSEN12.K Blok VI.Rincian 9a dan 9b. Jawaban responden akan dikategorikan menjadi dua, '0' layak dan ' 1 ' tidak layak.

b. Sanitasi Lingkungan $\left(\mathrm{X}_{2}\right)$

Variabel ini juga mengacu pada konsep MDGs dimana rumah tangga yang memiliki akses terhadap sanitasi layak adalah rumah tangga yang memiliki fasilitas buang air besar sendiri atau bersama dengan jenis kloset leher angsa dan tangki septik sebagai tempat pembuangan akhir tinja. Variabel ini diperoleh dari informasi kuesioner VSEN12.K Blok VI.Rincian13a, b, dan c. Variabel ini dikelompokkan menjadi dua, ' 0 ' sanitasi layak dan ' 1 ' sanitasi tidak layak.

c. Jenis lantai rumah $\left(\mathrm{X}_{3}\right)$

Jenis lantai rumah yang ditempati oleh rumahtangga responden diduga dapat mempengaruhi tingkat kesehatan anggota rumahtangga terutama balita. Variabel ini diperoleh melalui kuesioner VSEN12.K Blok VI. Rincian 7), dan dikelompokkan menjadi dua kategori, '0' bukan tanah dan '0' tanah.

\section{d. Usia balita $\left(\mathrm{X}_{4}\right)$}

Variabel usia balita adalah usia balita yang dianggap rentan terhadap berbagai penyakit terutama diare. Variabel ini dikelompokan menjadi dua kategori, yaitu: ' 0 ' usia $>=24$ bulan dan ' 1 ' usia $<24$ bulan).

e. Pendidikan kepala rumah tangga $\left(\mathrm{X}_{5}\right)$

Variabel ini diperoleh dengan menghitung rata-rata lama sekolah atau mean of years 
schooling (MYS) dari kepala rumah rangga balita. Variabel dibagi menjadi dua kategori, '0' MYS >= 12 tahun dan ' 1 ' MYS $<12$ tahun.

\section{f. Pemberian ASI $\left(\mathrm{X}_{6}\right)$}

Pemberian ASI adalah upaya ibu dalam memberikan asupan pertama kepada balita. Variabel ini dibagi menjadi dua kategori, '0' balita diberi ASI dan ' 1 ' balita tidak diberi ASI.

g. Keadaan ekonomi rumah tangga $\left(\mathrm{X}_{7}\right)$

Variabel keadaan ekonomi rumahtangga merupakan informasi kemampuan rumah tangga dalam memenuhi kebutuhan hidup sehari-hari. Keadan ekonomi rumah tangga dapat dilihat dari distribusi pendapatan dengan mengikuti kriteria Bank Dunia (World Bank), yaitu: distribusi pengeluaran per kapita $20 \%$ tertinggi; $40 \%$ menengah; dan $40 \%$ terendah. Variabel ini dapat diperoleh dengan mengolah data hasil hasil Susenas 2012 pada rincian 'rata-rata pengeluaran rumah tangga per kapita sebulan', dengan membagi menjadi tiga kategori, ' 0 ' kelompok $20 \%$ teratas, ' 1 ' kelompok $40 \%$ terbawah, dan ' 2 ' kelompok $40 \%$ menengah.

Analisis statistik pada penelitian ini menggunakan analisis regresi logistik. Analisis regresi logistik menjadi alat analisis yang penting untuk melihat sejauh mana hubungan antara variabel terikat dan variabel-variabel bebas apa saja yang paling signifikan berpengaruh terhadap penyebab risiko terjadinya diare pada balita di NTT tahun 2012.

\section{Hasil dan Pembahasan}

Distribusi frekuensi responden dimaksudkan untuk melihat perbedaan proporsi responden menurut kejadian diare pada balita. Selain itu digambarkan pula distribusi frekuensi sumber air minum yang digunakan dalam rumah tangga, keadaan sanitasi lingkungan, jenis lantai rumah, usia balita menurut bulan, pendidikan kepala rumah tangga, pemberian ASI, dan keadaan ekonomi rumahtangga.
Tabel 1. Distribusi frekuensi kejadian diare pada balita

\begin{tabular}{lcc}
\hline $\begin{array}{l}\text { Kejadian Diare } \\
\text { pada Balita }\end{array}$ & $\mathrm{n}$ & $\%$ \\
\hline $\begin{array}{l}\text { Ada kejadian } \\
\text { diare }\end{array}$ & 367 & 6.3 \\
$\begin{array}{l}\text { Tidak ada } \\
\text { kejadian diare } \\
\text { Total }\end{array}$ & 5416 & 93.7 \\
\hline
\end{tabular}

Berdasarkan tabel distribusi frekuensi tentang kejadian diare pada balita, terlihat bahwa dari keseluruhan balita (5.783 balita) yang ada dalam unit analisis terdapat 367 balita yang mengalami diare atau 6,3 persen. Data ini jika dibandingkan hasil survei yang lain seperti Riskesdas dan SDKI, maka masih tergolong rendah karena angkanya sudah di atas 10 persen.

Pada faktor sanitasi lingkungan, masih banyak rumahtangga di NTT yang sumber air minumnya tidak layak bahkan melebihi rumahtangga yang mengkonsumsi air minum dari sumber air minum yang sehat. Demikian juga halnya terhadap akses atau capaian sanitasi layak masih sangat rendah. Sekitar 75 persen rumahtangga yang memiliki balita di NTT menempati rumah sebagai tempat tinggal dengan kondisi sanitasi yang tidak layak. Artinya penggunaan tempat buang air besar (BAB) dengan kepemilikan sendiri atau bersama masih minim, apalagi dikatkan dengan jenis kloset dan tangki septik tempat pembuangan akhir kotoran.

Jika dibandingkan dengan kepemilikan jamban dan tempat pembuangan akhir kotoran dari hasil Sensus Penduduk 2010, keadaan ini masih cukup relevan, dimana hanya sekitar 32 persen rumahtangga di NTT yang menggunakan tempat BAB dengan kriteria sanitasi layak.

Rumahtangga di NTT yang mempunyai balita, ada sebanyak 46 persen lantai rumahnya masih dari jenis tanah. Apabila dibandingkan dengan keadaan seluruh rumahtangga di NTT hasil Susenas 2012 tanpa melihat adanya balita, ternyata juga masih cukup tinggi yaitu sekitar sepertiga rumahtangga yang berjenis lantai tanah. 
Distribusi usia balita yang dibagi menjadi 2 (dua) kategori yaitu balita 0-23 bulan dan 24-59 bulan, menggambarkan bahwa ada sebanyak 36,7 persen balita yang usianya kurang dari 24 bulan. Adapun distribusi pendidikan kepala rumahtangga yang memperlihatkan rata-rata lama sekolah dari kepala rumahtangga yang memiliki balita ada sebanyak 79,7 persen kepala rumah tangga yang lama pendidikannya kurang dari 12 tahun, artinya jika disetarakan dengan pendidikan tertinggi yang yang ditamatkan, maka mayoritas hanya memiliki ijazah SMP atau lebih rendah lagi. Selai itu, arakteristik rumahtangga tentang pemberian ASI menerangkan bahwa hanya ada 2 persen balita di NTT yang tidak diberi ASI.

Gambaran umum keadaan ekonomi rumahtangga hasil Susenas 2012 yang memiliki balita, dapat didekati dengan melihat distribusi pengeluaran rumahtangga per kapita. Dari tabel di atas dapat dikatakan bahwa mayoritas pengeluaran per kapita rumahtangga di NTT berada pada distribusi pengeluaran $40 \%$ terbawah yaitu sebesar 48,9 persen. Hal ini sangat relevan dengan kondisi kemiskinan di NTT yang tergolong tinggi jika dibandingkan dengan provinsi lain di Indonesia.

\subsection{Uji Signifikansi Model (Uji Simultan)}

Berdasarkan output yang diperoleh pada Tabel 4.16 dapat dibandingkan antara nilai statistik $G$ dengan nilai Chi square atau dengan membandingkan nilai $p$-value dgn taraf nyata $(\alpha)$. Nilai statistik $G$ pada model terbaik, yaitu 67.759, sedangkan nilai $\chi^{2}(8 ; 0,05)$ adalah 11,070 maka nilai $G$ lebih besar dibandingkan $\chi^{2}(8 ; 0,05)$ atau $G>\chi^{2}(8 ; 0,05)$. Selain itu, dapat juga dilihat dari nilai signifikansinya, yaitu nilai $p$-value sebesar 0,000 yang jauh lebih kecil dibandingkan taraf nyata $\alpha=0,05$, sehingga $H_{0}$ ditolak. Kesimpulan: model signifikan dengan tingkat kepercayaan $95 \%$, ada satu variabel bebas yang berpengaruh pada kejadian diare pada balita dan model dapat digunakan untuk analisis lebih lanjut.

\subsection{Uji Model Logistic Secara Parsial (Uji Wald)}

Tabel 2. Nilai penduga parameter, standar error, statistik uji wald, signifikansi, dan nilai odds ratio

\begin{tabular}{|c|c|c|c|c|c|}
\hline Variabel & $\mathrm{B}$ & S.E. & Wald & Sig. & $\begin{array}{c}\text { Exp (B) } \\
\text { Odds Ratio }\end{array}$ \\
\hline $\mathrm{X}_{1}-$ Sumber Air Minum & ,395 &, 117 & 11,410 &, 001 & 1,484 \\
\hline $\mathrm{X}_{2}$ - Sanitasi Layak & ,416 &, 165 & 6,346 & 012 & 1,516 \\
\hline $\mathrm{X}_{3}$ - Jenis Lantai & ,364 & ,119 & 9,280 & ,002 & 1,439 \\
\hline $\mathrm{X}_{4}$ - Usia Balita & ,258 &, 110 & 5,491 & ,019 & 1,294 \\
\hline $\mathrm{X}_{5}$ - Pendidikan KRT &, 345 &, 171 & 4,073 &, 044 & 1,412 \\
\hline $\mathrm{X}_{6}$ - Pemberian ASI & ,641 & ,327 & 3,852 &, 050 & 1,898 \\
\hline \multicolumn{6}{|l|}{$\mathrm{X}_{7}$ - Ekonomi rumah tangga } \\
\hline$X_{7}$ - (1) Distr Pengl. Rendah &,- 289 & ,196 & 2,160 &, 142 & ,749 \\
\hline$X_{7}-(2)$ Distr. Pengl. Sedang &, 102 &, 190 & ,288 &, 592 & 1,108 \\
\hline Constant & $-3,753$ & ,215 & 305,129 &, 000 & 023 \\
\hline
\end{tabular}


Berdasarkan Tabel 4.2 pada kolom Sig. (Significance) terlihat bahwa terdapat 6 (enam) variabel yang memiliki nilai kurang dari 0,05, yaitu: $\mathrm{X}_{1}$ (Sumber Air Minum), $\mathrm{X}_{2}$ (Sanitasi Lingkungan), $X_{3}$ (Jenis Lantai Rumah), $X_{4}$ (Usia Balita), $X_{5}$ (Pendidikan Kepala Rumah Tangga), dan $\mathrm{X}_{6}$ (Pemberian ASI). Oleh karena masingmasing memiliki nilai kurang dari 0,05 maka Ho ditolak atau dengan kata lain koefisien regresi signifikan. Secara rinci menurut variabel penjelas dapat diuraikan sebagai berikut:

\section{a. Sumber Air Minum}

Variabel Sumber Air Minum memiliki nilai Wald sebesar 11.410. Jika nilai Wald ini dibandingkan dengan nilai $\chi_{\text {tabel }}^{2}$, maka $\mathrm{H}_{0}$ ditolak karena nilai Wald (11.510) lebih besar dari $\chi_{(1 \text {; }}^{2}$ $0,05)=3,841$. Selain itu dapat juga dilihat dari nilai signifikansinya yaitu sebesar 0,001 yang lebih kecil dari nilai $\alpha=0,05$. Hal ini juga menunjukkan bahwa variabel air minum layak mempengaruhi kejadian diare pada balita. Hasil ini sejalan dengan penelitian Shinthamurniwaty (2006), Lusy Indrawati, dkk (1990) dan Trisno Agung Wibowo (2003) bahwa ketersediaan sarana air bersih (SAB) berpengaruh terhadap kejadian diare pada balita.

b. Sanitasi Layak

Variabel Sanitasi Lingkungan memiliki nilai Wald sebesar 6,346 dan jika dibanding dengan nilai $\chi_{\text {tabei }}^{2}$, maka nilai Wald lebih besar dari $\chi_{(1 ; 0,05)}^{2}$ yaitu $6,346>3,841$ sehingga $\mathrm{H}_{0}$ ditolak. Selain itu dapat juga dilihat dari nilai signifikansinya yaitu sebesar 0,012 yang lebih kecil dari nilai $\alpha=0,05$. Hal ini juga menunjukkan bahwa variabel sanitasi layak mempengaruhi kejadian diare pada balita. Hasil ini sejalan dengan penelitian Sumali M Atmojo (1998) dan Lusy Indrawaty,dkk (1990) bahwa sanitasi lingkungan berpengaruh terhadap kejadian diare pada balita.

c. Jenis Lantai Rumah

Variabel Jenis Lantai memiliki nilai Wald sebesar 9,280 dan jika dibanding dengan nilai $\chi_{\text {tabel }}^{2}$, maka nilai Wald lebih besar dari $\chi^{2}{ }_{(1 ; 0,05)}$ yaitu 9,280>3,841 sehingga $\mathrm{H}_{0}$ ditolak. Selain itu dapat juga dilihat dari nilai signifikansinya yaitu sebesar 0,002 yang lebih kecil dari nilai $\alpha=0,05$. Hal ini juga menunjukkan bahwa variabel Jenis Lantai Rumah mempengaruhi kejadian diare pada balita.

\section{d. Usia Balita}

Variabel Usia Balita memiliki nilai Wald sebesar 5,491 dan jika dibanding dengan nilai $\chi_{\text {tabel }}^{2}$, maka nilai Wald lebih besar dari $\chi_{(1 ; 0,05)}^{2}$ yaitu 5,491 > 3,841 sehingga $\mathrm{H}_{0}$ ditolak. Selain itu dapat juga dilihat dari nilai signifikansinya yaitu sebesar 0,019 yang lebih kecil dari nilai $\alpha=0,05$. Hal ini juga berarti menunjukkan bahwa variabel sanitasi layak mempengaruhi kejadian diare pada balita. Hasil ini sejalan dengan penelitian Wiwik Suharti (2000) dan Tonika Tohri (2004) bahwa usia balita mempengaruhi kejadian diare pada balita.

e. Pendidikan Kepala Rumah Tangga

Variabel Pendidikan Kepala Rumah Tangga dengan nilai Wald sebesar 4,073 dan jika dibanding dengan nilai $\chi_{\text {tabel }}^{2}$, maka nilai Wald lebih besar dari $\chi_{(1 ; 0,05)}^{2}$ yaitu $4.073>3,841$ sehingga $\mathrm{H}_{0}$ ditolak. Selain itu dapat juga dilihat dari nilai signifikansinya yaitu sebesar 0,044 yang lebih kecil dari nilai $\alpha=0,05$. Hal ini juga menunjukkan bahwa variabel Pendidikan Kepala Rumah Tangga mempengaruhi kejadian diare pada balita. Hasil ini sejalan dengan penelitian Syafie Ishak (2002) dan Sumali M Atmojo (1998) bahwa Pendidikan dari Sosek Keluarga mempengaruhi kejadian diare pada balita.

f. Pemberian ASI

Variabel Pemberian ASI pada balita dengan nilai Wald sebesar 3,852 dan jika dibanding dengan nilai $\chi_{\text {tabel }}^{2}$, maka nilai Wald lebih besar dari $\chi_{(1 ; 0,05)}^{2}$ yaitu $3,852>3,841$ sehingga $\mathrm{H}_{0}$ ditolak. Selain itu dapat juga dilihat dari nilai signifikansinya yaitu sebesar 0,012 yang lebih kecil dari nilai $\alpha=0,05$. Hal ini juga menunjukkan bahwa variabel Pemberian ASI berpengaruhi terhadap kejadian diare pada balita. Hasil ini sejalan dengan penelitian Lusy Indrawaty, dkk (1990) bahwa status gizi balita yang dalam hal ini 
diwakili dengan pemberian ASI pada balita berpengaruh terhadap kejadian diare pada balita.

g. Keadaan Ekonomi Rumah Tangga

Variabel Keadaan Ekonomi Rumah Tangga mempunyai nilai Wald sebesar 2,160 untuk rumah tangga dengan keadaan ekonomi rendah dan 0,288 untuk rumah tangga dengan keadaan ekonomi sedang. Jika dibanding dengan nilai $\chi_{\text {tabel }}^{2}$, maka nilai Wald lebih kecil dari $\chi^{2}{ }_{(1 ; 0,05)}$ sehingga $\mathrm{H}_{0}$ diterima. Selain itu dapat juga dilihat dari nilai signifikansinya yaitu sebesar 0,142 dan 0,592 yang lebih besar dari nilai $\alpha=0,05$. Hal ini juga menunjukkan bahwa variabel Keadaan Ekonomi Rumah Tangga tidak berpengaruh terhadap kejadian diare pada balita. Hasil ini tidak sejalan dengan penelitian Lusy Indrawaty, dkk (1990) tentang keadaan sosial ekonomi yang berpengaruh terhadap kejadian diare pada balita.

h. Pemberian ASI

Variabel Pemberian ASI pada balita dengan nilai Wald sebesar 3,852 dan jika dibanding dengan nilai $\chi_{\text {tabel }}^{2}$, maka nilai Wald lebih besar dari $\chi^{2}{ }_{(1 ; 0,05)}$ yaitu $3,852>3,841$ sehingga $\mathrm{H}_{0}$ ditolak. Selain itu dapat juga dilihat dari nilai signifikansinya yaitu sebesar 0,012 yang lebih kecil dari nilai $\alpha=0,05$. Hal ini juga menunjukkan bahwa variabel Pemberian ASI berpengaruhi terhadap kejadian diare pada balita. Hasil ini sejalan dengan penelitian Lusy Indrawaty, dkk (1990) bahwa status gizi balita yang dalam hal ini diwakili dengan pemberian ASI pada balita berpengaruh terhadap kejadian diare pada balita.

i. Keadaan Ekonomi Rumah Tangga

Variabel Keadaan Ekonomi Rumah Tangga mempunyai nilai Wald sebesar 2,160 untuk rumah tangga dengan keadaan ekonomi rendah dan 0,288 untuk rumah tangga dengan keadaan ekonomi sedang. Jika dibanding dengan nilai $\chi_{\text {tabel }}^{2}$, maka nilai Wald lebih kecil dari $\chi^{2}(1 ; 0,05)$ sehingga $\mathrm{H}_{0}$ diterima. Selain itu dapat juga dilihat dari nilai signifikansinya yaitu sebesar 0,142 dan 0,592 yang lebih besar dari nilai $\alpha=0,05$. Hal ini juga menunjukkan bahwa variabel Keadaan Ekonomi Rumah Tangga tidak berpengaruh terhadap kejadian diare pada balita. Hasil ini tidak sejalan dengan penelitian Lusy Indrawaty, dkk (1990) tentang keadaan sosial ekonomi yang berpengaruh terhadap kejadian diare pada balita.

\subsection{Analisis Odds Ratio}

Sesuai penjelasan pada Bab III bahwa Odds Ratio dalam Regresi Logistic dapat digunakan untuk mengetahui resiko kecenderungan variabelvariabel penjelas yang mempengaruhi terjadinya diare pada balita. Dari hasil pengolahan dengan program SPSS 16.0 untuk masing-masing variabel penjelas dapat dilihat pada output tabel variables in the equation kolom $\exp (\beta)$. Interpretasi dari nilai odds ratio pada tabel di atas adalah:

a. Sumber Air Minum

Variabel sumber air minum mempunyai nilai koefisien positif 0,395 dan Exp (B) atau nilai odds ratio sebesar 1,484 . Ini berarti rumah tangga dengan sumber air minum yang tidak layak memiliki kecenderungan terjadinya diare pada balita dibanding rumah tangga dengan sumber air minum yang layak, artinya rumah tangga balita yang memiliki sumber air minum tidak layak memiliki peluang yang lebih besar terjadi kejadian diare pada balitanya. Nilai odds ratio sebesar 1,484 memberikan arti bahwa kecenderungan rumah tangga yang memiliki sumber air minum tidak layak mengalami kejadian diare pada balita 1,484 kali lebih besar dibandingkan dengan rumah tangga dengan sumber air minum yang layak. Hal ini juga berarti perbaikan fasilitas sumber air minum akan berdampak positif terhadap penurunan kejadian diare pada balita.

b. Sanitasi Lingkungan

Variabel sanitasi lingkungan mempunyai nilai koefisien positif 0,416 dan $\operatorname{Exp}$ (B) atau nilai odds ratio sebesar 1,516. Ini berarti rumah tangga dengan sanitasi lingkungan yang tidak layak memiliki kecenderungan terjadinya diare pada balita dibanding rumah tangga dengan sanitasi lingkungan yang layak, artinya rumah tangga balita yang memiliki sanitasi lingkungan tidak layak memiliki peluang yang lebih besar terjadi 
kejadian diare pada balitanya. Nilai odds ratio sebesar 1,516 memberikan arti bahwa kecenderungan rumah tangga yang memiliki sanitasi lingkungan yang tidak layak mengalami kejadian diare pada balita 1,516 kali lebih besar dibandingkan dengan rumah tangga dengan sanitasi lingkungan yang layak. Hal ini juga berarti perbaikan fasilitas lingkungan yang sehat akan berdampak positif terhadap penurunan kejadian diare pada balita.

\section{c. Jenis Lantai Rumah}

Variabel Jenis lantai rumah mempunyai nilai koefisien positif 0,364 dan $\operatorname{Exp}$ (B) atau nilai odds ratio sebesar 1,439 . Ini berarti rumah tangga dengan jenis lantai tanah memiliki kecenderungan terjadinya diare pada balita dibanding rumah tangga dengan jenis lantai rumahnya bukan tanah, artinya rumah tangga balita yang memiliki jenis lantai tanah memiliki peluang yang lebih besar terjadi kasus diare pada balitanya. Nilai odds ratio sebesar 1,439 memberikan arti bahwa kecenderungan rumah tangga yang memiliki jenis lantai tanah mengalami kejadian diare pada balita 1,439 kali lebih besar dibandingkan dengan rumah tangga dengan lantai bukan tanah.

\section{d. Usia Balita}

Variabel usia balita mempunyai nilai koefisien positif 0,258 dan Exp (B) atau nilai odds ratio sebesar 1,294. Ini berarti rumah tangga dengan usia balita kurang dari 24 bulan mempunyai kecenderungan terjadinya diare pada balita dibanding rumah tangga yang memiliki balita berusia 24 bulan sampai dengan 59 bulan. Hal ini menunjukkan bahwa rumah tangga yang memiliki balita berusia kurang dari 24 bulan memiliki peluang yang lebih besar terjadi kejadian diare pada balitanya. Nilai odds ratio sebesar 1,294 memberikan arti bahwa kecenderungan rumah tangga yang memiliki balita berusia kurang dari 24 bulan mengalami kejadian diare pada balita 1,294 kali lebih besar dibandingkan dengan rumah tangga dengan balita berusia 24 bulan sampai dengan 59 bulan.

e. Pendidikan Kepala Rumah Tangga

Variabel kepala rumah tangga mempunyai nilai koefisien positif 0,345 dan Exp (B) atau nilai odds ratio sebesar 1,412 . Ini berarti rumah tangga dengan rata-rata lama pendidikan kepala rumahtangganya kurang dari 12 tahun atau setara dengan tamatan SMP ke bawah memiliki kecenderungan terjadinya diare pada balita dibanding rumah tangga rata-rata pendidikan kepala rumahtanggnya minimal 12 tahun atau setara dengan tamat SMA ke atas. Hal ini menunujukkan bahwa semaikin rendah pendidikan kepala rumah tangga maka semakin mempunyai peluang yang lebih besar terjadi kasus diare pada balitanya. Nilai odds ratio sebesar 1,412 memberikan arti bahwa kecenderungan rumah tangga yang memiliki kepala rumah tangga dengan rata-rata lama sekolahnya kurang dari 12 tahun mengalami kejadian diare pada balita 1,412 kali lebih besar dibandingkan dengan rumah tangga dengan kepala rumah rangga yang rata-rata lama sekolahnya minimal 12 tahun ke atas.

\section{f. Pemberian ASI}

Variabel pemberian ASI pada balita mempunyai nilai koefisien positif 0,641 dan Exp (B) atau nilai odds ratio sebesar 1,898. Ini berarti balita yang tidak diberi ASI memiliki kecenderungan terjadinya diare dibanding balita yang diberi ASI, artinya balita yang tidak diberi ASI memiliki peluang yang lebih besar terjadi kasus diare pada balitanya. Nilai odds ratio sebesar 1,898 memberikan arti bahwa kecenderungan balita yang tidak diberi ASI akan mengalami kejadian diare pada sebanyak 1,439 kali lebih besar dibandingkan dengan balita yang diberi ASI.

\section{g. Keadaan Ekonomi Rumah Tangga}

Variabel keadaan ekonomi rumah tangga yang dihitung melalui distribusi pengeluaran rumahtangga per kapita dengan 3 kategori: $40 \%$ bawah, $40 \%$ menengah, dan $20 \%$ atas, ternyata tidak signifikan mempengaruhi kejadian diare pada balita. Ini berarti tidak ada perbedaan terjadinya kejadian diare pada rumah tangga dengan distibusi pengeluaran per kapita sedang dan kecil, demikian pula antara rumah tangga dengan distribusi pengeluaran per kapita tinggi dan kecil. 


\section{Simpulan}

Berdasarkan hasil penelitian dapat ditarik beberapa kesimpulan sebagai berikut:

1) Faktor sanitasi lingkungan tempat tinggal yang terdiri dari sumber air minum, sanitasi layak, dan jenis lantai mempunyai pengaruh positif terhadap kejadian diare pada balita.

2) Karakteristik sosial ekonomi rumahtangga mempunyai pengaruh positif terhadap kejadian diare pada balita kecuali keadaan ekonomi rumahtangga.

3) Besarnya pengaruh faktor sanitasi lingkungan: Rumahtangga dengan sumber air minum tidak layak memiliki peluang terjadinya diare pada balita sebesar 1,484 kali dibanding rumahtangga dengan sumber air minum layak, sanitasi tidak layak sebesar 1,516 kali dibanding sanitasi yang tidak layak, dan jenis lantai rumah dari tanah sebesar 1,439 kali dibanding bukan tanah.

4) Besarnya pengaruh karakteristik sosial ekonomi rumahtangga: Usia balita mempunyai nilai Odds Ratio (OR) sebesar 1,294 . Ini berarti balita dengan usia $0-23$ bulan memiliki peluang terjadinya diare sebesar 1,294 kali dibanding balita usia 24-59 bulan, pendidikan kepala rumahtangga yang tamat SMP ke bawah sebesar 1,412 kali dibanding kepala rumahtangga dengan pendidikan SMA ke atas, dan balita yang tidak diberi ASI memiliki peluang terbesar terjadinya diare pada balita yaitu 1,898 kali dibanding balita yang diberi ASI.

\section{Daftar Pustaka}

Adisasmito, W. 2007. Faktor Risiko Diare Pada Bayi dan Balita di Indonesia : Systematic Review Penelitian Akademik Bidang Kesehatan Masyarakat, Makara, Kesehatan, Vol.11, No.1, Juni 2007:1-10.
Adisantoso, J. 2010. Model Log-Liner dan Regresi Logistik, G16109011 / STK.

Agresti, A. 2002. Categorical Data Analysis, Second Edition. John Wiley \& Sons Inc. ISBN: 0-471-36093-7.

Amaliah, S. 2010. Hubungan Sanitasi Lingkungan dan Faktor Budaya dengan Kejadian Diare pada Anak Balita di Desa Toriyo Kecamatan Bendosari Kabupaten Sukoharjo. Prosiding Seminar Nasional Unimus. 2010. Semarang.

Arif, G. M dan Sabiha Ibrahim. 1998. Diarrhoea Morbidity Differentials among children in Pakistan. The Pakistan Development Review 37:3, 205-230.

Arif, Asma dan Rukhsana Naheed. 2012. Sosioeconomic Determinants of Diarrhoea Morbidity in Pakistan. Academic Research International. Vol. 2, No. 1, January 2012.

Atmojo. S.M. (1998). Faktor-faktor yang mempengaruhi Kejadian Diare Anak Balita di Kabupaten Purworejo, Jawa Tengah. Institut Pertanian Bogor.

Badan Perencanaan Pembangunan Nasional (Bappenas). 2007. Laporan Perkembangan Pencapaian Millenium Development Goals Indonesia, Kementerian Negara Perencanaan Pembangunan Nasional/Badan Perencanaan Pembangunan Nasional, 2007,

Badan Perencanaan Pembangunan Nasional. 2009. Faktor-Faktor yang Mempengaruhi Kelangsungan Hidup Anak. Badan Perencanaan Pembangunan Nasional: Jakarta.

Badan Pusat Statistik, 2012. Buku Pedoman Kepala BPS Provinsi dan Kabupaten/Kota, Jakarta, BPS, 2012.

Badan Pusat Statistik, 2012. Survei Demografi dan Kesehatan Indonesia (SDKI) 2012, BPS, 2014

Baroroh, A. 2013. Analisis Multivariat dan Time Series dengan SPSS 21, PT Elex Media Komputindo, Jakarta, 2013. 
Chiras, Daniel D. 1985. Environmental Science, A Frame Work For Decisien Making, Menlo Park USA, The Benyamin/Cummingas. Publishing Company.

Dadi. 2000. Pengaruh Kondisi Sanitasi Lingkungan Terhadap Kematian Anak (Analisis Data SDKI 1997). UI.

Depkes RI, Buku Pedoman Pemberantasan Penyakit Diare dalam Repelita VI, Jakarta, 1990.

Esrey, S.A., et al. 1991. Effects of Improved Water Supply and Sanitation on Ascariasis, Diarrhoea, Dracunculiasis, Hookworm Infection, Schistosomiasis and Trachoma. Bulletin of World Health Organization, 69 (5) 609-621.

Fardiani. 2002. Faktor Lingkungan yang Berhubungan Dengan Kejadian Malaria di Kecamatan Nongsa Kota Batam. UI.

Ferdous, Fersana., et al. 2013. The impact of socio-economic conditions and clinical characteristics on improving childhood care seeking behaviors for families living far from the health facility. Science Journal of Public Health 2013; 1(2): 69. 76

Fewtrell, Lorna., et al. 2005. Water, sanitation, and hygiene interventions to reduce diarrhoea in less developed countries: a systematic review and meta-analysi. Lancet Infect Dis 2005; 5: 42-52.

Herwandi, Y.; Abdurrahman, H.M.; Sya, H.M.A. 2008. Hubungan Antara Pengetahuan Kepala Keluarga Tentang Kesehatan Lingkungan dan Tingkat Kesejahteraan Keluarga dengan Derajat Kesehatan Lingkungan Keluarga di Desa Wanakerta Kecamatan Cibatu Kabupaten Garut.

Hosmer, D. W. and Lemeshow Stanley, Applied Logistic Regression Second Edition, Copyright 2000 John Wiley \& Sons, Inc, ISBN: 0-471-72214-6

Irwan, D.Z.1996. Prinsip-prinsip Ekologi, Ekosistem, Lingkungan dan Pelestariannya. Cetakan keenam, PT Bumi Aksara, Maret 2010
Kementerian Kesehatan RI. 2011. Situasi Diare di Indonesia, Buletin Jendela Data dan Informasi Kesehatan Volume, TRIWULAN 2, 2011, Jakarta.

Lismarni. 2006. Pengaruh Lingkungan Fisik Rumah Terhadap Tersangka Penderita TBC Paru di Indonesia Tahun 2004 (Analisis Lanjut Data Susenas 2004). Universitas Indonesia.

Lopez-Alarco, Mardya., et al. 1997. BreastFeeding Lowers the Frequency and Duration of Acute Respiratory Infection and Diarrhea in Infants under Six Months of Age. American Society for Nutritional Sciences 0022-3166/97.

Luby, Stephen P. 2011. The Variability of Childhood Diarrhea in Karachi, Pakistan, 2002-2006. The American Society of Tropical Medicine and Hygiene 84(6), 2011, pp. 870-877.

Mock, Nancy B., et al. 1993. Sosioeconomic, Enviromental, Demographic and Behavioral Factors Associated With Occurrence of Diarrhea in Young Children In The Republic of Congo. Sot. Sci. Med. Vol. 36, No. 6, pp. 807-816.

Otto Soemarwoto. 1997. Ekologi, Lingkungan Hidup dan Pembangunan. Jakarta : Djambatan.

Rohmawati, Nida. 2010. Factors Associated With Diarrhea Among Under-Five Years Old Children in Banten Province Indonesia: A Secondary Analysis Of Indonesian National Social-Economic Survey 2007 And Basic Health Research 2007. Chulalongkorn University.

Rishi, P., et al. 2010. Risk Factors and Case Management of Acute Diarrhoe in North Gondar Zone, Ethiopia. Jurnal of Health Population and Nutrition June; 28(3):253263.

Sarwono, J. 2013. 12 Jurus Ampuh SPSS untuk Riset Skripsi (Kupas Tuntas Prosedurprosedur Regresi dan 'Decision Trees' dalam IBM SPSS), PT Elex Media Komputindo, Jakarta, 2013. 
Senaur, Benjamin dan Ana L. Kassouf . 2000. The effect of breast feeding on health and the Demand for medical Assistance among children in Brazil. Economic Development and Cultural Change ,Volume 48, No.4.

Sinthamurniwaty. 2006. Faktor-faktor Risiko Kejadian Diare Akut Pada Balita (Studi Kasus di Kabupaten Semarang). Universitas Diponegoro, Semarang.

Suharti. W. 2000. Status Gizi dan Karakteristik Balita Diare di Ruang Rawat Inap RSUD Dr. H. Soemarmo Sosroatmodjo Kuala Kapuas, Kalimantan Tengah. Universitas Gajah Mada.

Tsui, Amy Ong., et al. 1988. Maternal and Sociodemographic Correlates of Child Morbidity in Bas Zaire: The Effects of Maternal Repoting. Sot. Sci. Med. Vol. 26. No. 7, pp. 701-713.
World Health Organization/The United Nations Children's Fund (UNICEF) 2013. Ending preventable deaths: Global Action Plan for Prevention and Control of Pneumonia and Diarrhoea. The integrated Global Action Plan for Pneumonia and Diarrhoea (GAPPD). WHO: France.

World Health Organization/The United Nations Children's Fund (UNICEF) 2009. Diarrhoea: Why children are still dying and what can be done. WHO: Geneva.

World Bank. 2002. Poverty Reduction Strategy Papers (PRSP) Source Book.

Zein, U.; Sagala. K.H.; Ginting, J. 2004. Diare Akut Disebabkan Bakteri. USU.

Zulkifli. 2003. Analisis Faktor-Faktor yang Berhubungan dengan Kejadian Diare Untuk Menentukan Kebijakan Penanggulangan Diare di Wilayah Kerja Puskesmas Kecamatan Mutiara Kabupaten Pidie Tahun 2003. USU. 